\title{
COMPOSITION AND STRUCTURE VEGETATION OF LOWANG GALI TOURISM FOREST, EAST LOMBOK REGENCY
}

\author{
Ahmad Nawawi ${ }^{1}$, Firman Ali Rahman ${ }^{2 *}$, Maya Ekaningtias ${ }^{1}$, Alfian Pujian Hadi ${ }^{3}$, Ahmad \\ Fadli ${ }^{1}$ \\ ${ }^{1}$ Biology Education Study Program, Teacher Training and Education Faculty - Nahdlatul Wathan Mataram University \\ ${ }^{2}$ Biology Education Department - State Islamic University of Mataram \\ ${ }^{3}$ Geography Education Study Program, Teacher Training and Education Faculty - Muhammadiyah Mataram University \\ *Corresponding author, temail: firmanalirahmanlombok@gmail.com
}

\begin{abstract}
ARTICLE INFO
Article history

Received $04^{\text {th }}$ of Sept., 2020

Revised $10^{\text {th }}$ of Sept, 2020

Accepted $13^{\text {th }}$ of Oct, 2020

Published $12^{\text {th }}$ of Nov, 2020

Keywords

Lowang Gali Tourism -Forest

Important Value Index

East Lombok Regency

Composition

Vegetation Structure
\end{abstract}

\section{ABSTRACT}

The composition and structure of vegetation is one way to determine the level of control and distribution of a habitat, including in Lowang Gali forest tourism which has the potential as an educational tourism area in East Lombok Regency. Based on the observations, there were 14 families with 22 species of woody plants. The moraceae family is the family with the largest number of species, consisting of 5 (five) ficus genera, namely: Ficus racemosa, Ficus salicifolia, Ficus variegate, Ficus sur and Ficus seftica. Based on the results of data analysis, the highest Important Value Index for seedlings was Ficus seftica $(23,39 \%)$, the highest sapling was Alstonia scholaris $(19,80 \%)$, the highest pile strata was Dysoxylium gaudichadianun $(50,44 \%)$ and tree strata. the highest were Alstonia scholaris $(45,15 \%)$ and Dysoxylium gaudichadianun $(45,15 \%)$. The index value of plant species diversity in the Lowang Gali forest tourism area is more than $1\left(1 \leq \mathrm{H}^{\prime} \leq 3\right)$ which indicates moderate diversity.

Copyright $(9) 2020$, Nawawi, et al.

This is an open access article under the CC-BY-SA license

\section{A. INTRODUCTION}

Indonesia is one of the countries that have a high biodiversity, among which there are $17 \%$ of the total number of flora and fauna scattered throughout the world, this is evidenced by Indonesia is the seventh-largest country with 20,000 species, $40 \%$ of which are endemic to Indonesia Kusmana and Istomo, (1995). The high level of biodiversity in Indonesia can be attributed to Indonesia being a tropical country so that flora and fauna can easily adapt and do not have severe barriers to growth and development. Apart from that, it is supported by Indonesia's geographical location which is on the equator.

One of the islands that have natural resources rich in flora and fauna is the island of Lombok, West Nusa Tenggara Province. Lombok Island is one of the islands in the small Sundanese region which has lowland tropical rainforest and semi-evergreen rain areas such as the Mount Rinjani National Park (TNGR) forest area (Monk et al., 1997). One of the natural potentials that have high diversity on the island of Lombok is the Lowang Gali 
tourism forest located in the village of Ramban Biak, Lenek District, East Lombok Regency. Lowang Gali Tourism is a forest area that is used as a natural tourism and educational tour.

The potential for vegetation diversity in the Lowang Gali forest tourism is one of the important factors for educational tourism besides the potential for natural tourism that is presented, but until now there has been no research related to the inventory of plant species diversity, so this research is the first step in exploring the potential for educational tourism.

\section{B. METHOD}

\section{Time and Place of Research}

This research was conducted in July-August 2020 in the forest tourism area of Lowang Gali, Ramban Biak village, Lenek district, East Lombok Regency, with a research area of \pm 13 hectares (Figure 2.1).

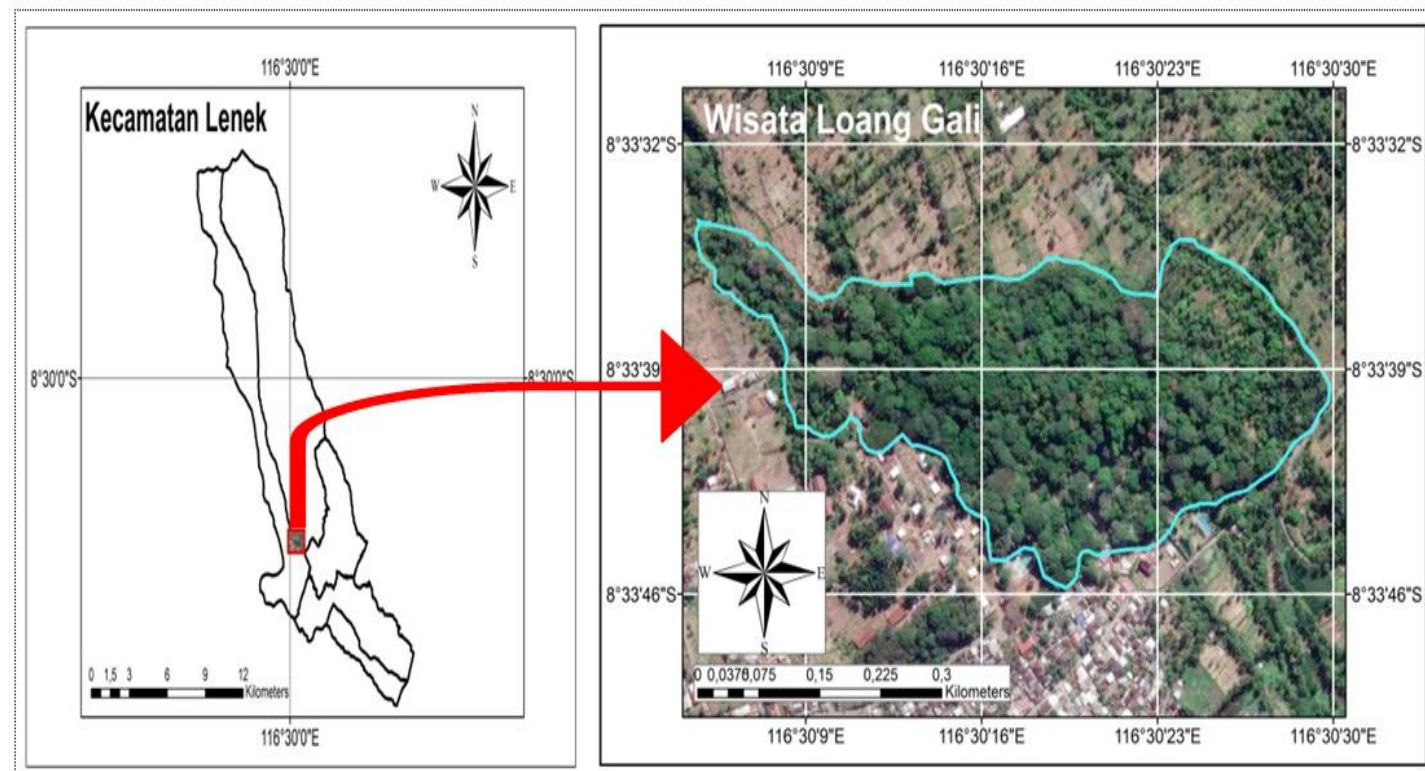

Figure 2.1. The Research Location Of The Lowang Gali Forest Tourism Area, East Lombok

\section{Tools and Materials}

The tools used in this study were raffia ropes, stakes, tape measure, GPS, label paper, plastic samples, cameras, stationery and sample rulers. Meanwhile, the ingredients needed are leaves, flowers, and plant fruit as identification materials.

\section{Research Methods}

Observation and data collection of vegetation were carried out using the randomized plot method by making different quadrants for each plant strata (Figure 2.2), namely: strata seedlings at $2 \times 2 \mathrm{~m}$ size, saplings strata at $5 \times 5 \mathrm{~m}$ size, poles strata at $10 \times 10 \mathrm{~m}$ size, and trees at quadrant size $15 \times 15 \mathrm{~m}$. The number of observation and measurement quadrant plots was 25 sample plots. 


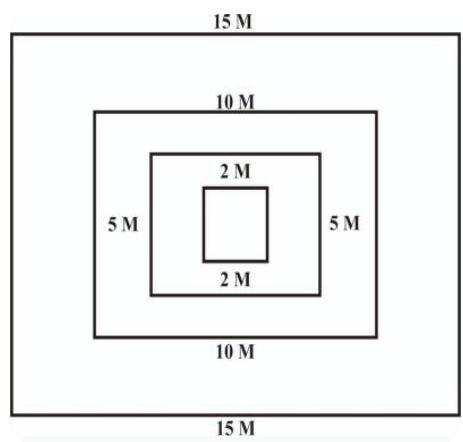

Figure 2.2. Research Metrics

$$
\begin{aligned}
& \text { Frequency }=\frac{\text { The number of tiles containing a type }}{\text { The number of observation quadrant plots }} \\
& \text { Relative frequency }=\frac{\text { Frequency of kind }}{\text { Frequency of all kind }} \times 100 \% \\
& \text { Density } \\
& =\frac{\text { Number of individual }}{\text { Quadrant plot area }} \\
& \text { Relative density }=\frac{\text { One type density }}{\text { All of type density }} \times 100 \%
\end{aligned}
$$

Base area$$
=1 / 4 \cdot \pi \cdot \mathrm{D}^{2}
$$

Dominance

$$
=\frac{\text { The base area of one type }}{\text { The total area of the sample plot }}
$$

Relative dominance $=\frac{\text { The cover of type }}{\text { All of the cover types }} \times 100 \%$

Importance Value Index = Relative frequency + Relative density + Relative dominance

The diversity index is determined using the Shannon-Wiener formula, namely

$$
\mathrm{H} \text { '= - } \sum \mathrm{Pi} \text { Ln Pi }
$$

Information:

$$
\begin{aligned}
& \mathrm{H}^{\prime}=\text { diversity index } \\
& \mathrm{Pi}=\mathrm{ni} / \mathrm{N} \\
& \text { ni }=\text { density } \\
& \mathrm{N}=\text { density of all species }
\end{aligned}
$$

Shannon-Wiener diversity assessment criteria (Restu, 2002)

1. If the value of $H^{\prime}<1$, indicates that the diversity is small.

2. If the value of $1<\mathrm{H}^{\prime}<3$, it indicates that the diversity is moderate.

3. If the value of $\mathrm{H}^{\prime}>3$, it shows that the diversity is high.

\section{RESULTS AND DISCUSSION}

Composition of Plant Types Based on the observations, it was found 14 families with a total of 22 species of woody plants in Lowang Gali forest tourism (Table 3.1). The moraceae family is the family with the largest number of species, consisting of 5 (five) ficus genera, namely: Ficus racemosa, Ficus salicifolia, Ficus variegate, Ficus sur and Ficus seftica. The number of ficus clans found than other genera can be caused by tourism in the Lowang Gali forest in lowland areas, this is supported by Nur'aini et al., (2013) 
report that most species of the genus ficus are found in tropical areas and grow well in lowland areas.

Table 3.1. Composition of Lowang Gali forest tourism plant species

\begin{tabular}{llcccc}
\hline No & \multicolumn{1}{c}{ Species } & Seedling & Sapling & Pole & Tree \\
\hline 1 & Alstonias cholaris & $\checkmark$ & $\checkmark$ & $\checkmark$ & $\checkmark$ \\
2 & Azadirachta indica & $\checkmark$ & - & $\checkmark$ & $\checkmark$ \\
3 & Baringtonia racemosa & $\checkmark$ & $\checkmark$ & $\checkmark$ & $\checkmark$ \\
4 & Brugmansia sp & $\checkmark$ & $\checkmark$ & - & - \\
5 & Calophyllum inophyllum & $\checkmark$ & $\checkmark$ & $\checkmark$ & $\checkmark$ \\
6 & Ceiba speciosa & - & $\checkmark$ & - & $\checkmark$ \\
7 & Dendrocnide stimulans & $\checkmark$ & $\checkmark$ & $\checkmark$ & $\checkmark$ \\
8 & Dysoxylium gaudichadianun & $\checkmark$ & $\checkmark$ & $\checkmark$ & $\checkmark$ \\
9 & Dysoxylium sp & $\checkmark$ & $\checkmark$ & $\checkmark$ & $\checkmark$ \\
10 & Ficus racemosa & $\checkmark$ & $\checkmark$ & $\checkmark$ & $\checkmark$ \\
11 & Ficus salicifolia & - & - & $\checkmark$ & $\checkmark$ \\
12 & Ficus seftica & $\checkmark$ & $\checkmark$ & $\checkmark$ & - \\
13 & Ficus sur & $\checkmark$ & $\checkmark$ & $\checkmark$ & - \\
14 & Ficus variegate & $\checkmark$ & $\checkmark$ & $\checkmark$ & $\checkmark$ \\
15 & Gmelina arborea & - & $\checkmark$ & $\checkmark$ & $\checkmark$ \\
16 & Leuccaena sp & $\checkmark$ & $\checkmark$ & - & - \\
17 & Salix tetrasperma & $\checkmark$ & $\checkmark$ & - & $\checkmark$ \\
18 & Shorea macrophylla & - & $\checkmark$ & $\checkmark$ & $\checkmark$ \\
19 & Shorea sp & $\checkmark$ & - & $\checkmark$ & $\checkmark$ \\
20 & Sumbucus javanica & $\checkmark$ & $\checkmark$ & - & - \\
21 & Syzygium aqueum & $\checkmark$ & $\checkmark$ & - & - \\
22 & Tabernamontana sphaeracorpa & $\checkmark$ & $\checkmark$ & $\checkmark$ & - \\
\hline
\end{tabular}

In contrast to the composition of the forest vegetation in the Gunung Rinjani National Park (TNGR) that the dominant species are Peterospermum javanicum, Sizygium sp and Antidesma sp namely the TNGR area is a highland habitat while Lowang Gali Tourism is in the lowlands.

The important value index is one way of calculating the level of mastery of a research object which can be in the form of plants (Rahman et al., 2018). The index of a forest vegetation is highly dependent on habitat conditions which can be influenced by environmental factors so that certain types that can survive, grow and develop well can be seen from the Important Value Index of the types of field observations and data analysis (Rahman et al., 2019). Based on the results of field observations and data analysis (Table 3.2), the highest Important Value Index in the seedling strata was Ficus seftica (23.39\%). Lowland, this is in accordance with the topographical conditions of Lowang Gali Tourism which is a lowland so that it supports the process of growth and development, this is in accordance with the results of research by Nur'aini et al., (2013) in Prof. Soemirto Djojo Hadikusumo stated that Ficus seftica was the type with the highest Important Value Index for seedling strata.

While the lowest Important Value Index is the type of Azadirachta indica with an Important Value Index of $3.95 \%$, this can be because Azadirachta indica is difficult to adapt to humid climates but can grow and develop well in dry areas (Ahmad and Grainge, 1985; Susila, 2014). 
Table 3.2. Importance index for seedling strata

\begin{tabular}{llrrr}
\hline \multirow{2}{*}{ No } & \multicolumn{1}{c}{ Species } & $\begin{array}{c}\text { Relative } \\
\text { density }(\%)\end{array}$ & $\begin{array}{c}\text { Relative } \\
\text { frequency }(\%)\end{array}$ & $\begin{array}{r}\text { Important Value } \\
\text { Index }(\%)\end{array}$ \\
\hline 1 & Alstonia scholaris & 9,09 & 7,317 & 16,41 \\
2 & Azadirachta indica A. Juss & 1,51 & 2,43 & 3,95 \\
3 & Baringtonia racemosa & 3,03 & 4,87 & 7,91 \\
4 & Brugmansia sp & 3,03 & 2,43 & 5,47 \\
5 & Calophyllum inophyllum & 3,03 & 7,31 & 10,35 \\
6 & Dendrocnide stimulans & 3,03 & 2,43 & 5,47 \\
7 & Dysoxylium gaudichadianun & 12,12 & 9,75 & 21,88 \\
8 & Dysoxylium sp & 3,03 & 2,43 & 5,47 \\
9 & Ficus racemosa & 3,03 & 4,87 & 7,91 \\
10 & Ficus seftica & 13,63 & 9,75 & 23,39 \\
11 & Ficus sur & 10,60 & 7,31 & 17,92 \\
12 & Ficus variegate & 7,57 & 7,31 & 14,89 \\
13 & Leuccaena sp & 4,54 & 4,87 & 9,42 \\
14 & Salix tetrasperma & 3,03 & 2,43 & 5,47 \\
15 & Shorea sp & 4,54 & 4,87 & 9,42 \\
16 & Sumbucus javanica & 7,57 & 7,31 & 14,89 \\
17 & Syzygium aqueum & 3,03 & 4,87 & 7,91 \\
18 & Tabernamontana sphaeracorpa & 4,54 & 7,31 & 11,86 \\
\hline & Total & 100 & 100 & 200 \\
\hline
\end{tabular}

Table 3.3. Importance value index for saplings strata

\begin{tabular}{|c|c|c|c|c|}
\hline No & Spesies & $\begin{array}{c}\text { Relative } \\
\text { density }(\%)\end{array}$ & $\begin{array}{c}\text { Relative } \\
\text { frequency }(\%)\end{array}$ & $\begin{array}{c}\text { Important Value } \\
\text { Index }(\%)\end{array}$ \\
\hline 1 & Alstonia scholaris & 8,92 & 10,8 & 19,80 \\
\hline 2 & Baringtonia racemosa & 3,57 & 4,34 & 7,92 \\
\hline 3 & Brugmansia sp & 5,35 & 4,34 & 9,70 \\
\hline 4 & Calophyllum inophyllum & 3,57 & 2,17 & 5,74 \\
\hline 5 & Ceiba speciosa & 3,57 & 4,34 & 7,91 \\
\hline 6 & Dendrocnide stimulans & 7,14 & 6,52 & 13,66 \\
\hline 7 & Dysoxylium gaudichadianun & 5,35 & 6,52 & 11,88 \\
\hline 8 & Dysoxylium $\mathrm{sp}$ & 7,14 & 4,34 & 11,49 \\
\hline 9 & Ficus racemosa & 1,78 & 2,17 & 3,96 \\
\hline 10 & Ficus seftica & 7,14 & 4,34 & 11,49 \\
\hline 11 & Ficus sur & 5,35 & 6,52 & 11,88 \\
\hline 12 & Ficus variegate & 7,14 & 4,34 & 11,49 \\
\hline 13 & Gmelina arborea & 3,57 & 4,34 & 7,919 \\
\hline 14 & Leuccaena sp & 7,14 & 8,69 & 15,84 \\
\hline 15 & Salix tetrasperma & 5,35 & 4,34 & 9,70 \\
\hline 16 & Shorea macrophylla & 1,78 & 2,17 & 3,96 \\
\hline 17 & Sumbucus javanica & 7,14 & 8,69 & 15,84 \\
\hline 18 & Syzygium аquеит & 3,57 & 4,34 & 7,92 \\
\hline \multirow[t]{2}{*}{19} & Tabernamontana sphaeracorpa & 5,35 & 6,52 & 11,88 \\
\hline & Total & 100 & 100 & 200 \\
\hline
\end{tabular}

The highest Important Value Index in saplings strata is Alstonia scholaris with a value of $19.80 \%$ (Table 3.3), the interesting thing is the level of mastery of Alstonia scholaris is lower in the seedling strata compared to Ficus seftica, it can be assumed that Alstonia scholaris saplings need sufficient sunlight for growth and development. While the condition of the Lowang Gali Tourism habitat is shaded vegetation which causes the growth and development of Alstonia scholaris to be relatively slower, in contrast to Alstoniascholaris in the sapling strata that has begun to dominate with the highest 
Important Value Index which can be due to the ability to receive sufficient light intensity without being blocked by other plants.

The highest Important Value Index for saplings strata is the type Dysoxylium gaudichadianun with a value of $50.44 \%$ (Table 3.4), the results of this study are different from the results of research conducted by Sofiah et al., (2013) low (5.62\%), this proves that the ability to grow and adapt to the Dysoxylium gaudichadianu species is low in mountainous areas and conversely has the ability to grow and adapt well in lowland areas such as in the Lowang Gali forest tourism.

The lowest Important Value Index for pole strata was Gmelina arbore and Azadirachta indica with the same value, namely $7.86 \%$. Factors that can cause the low Important Value Index of Gmelina arbore can be due to limiting factors for growth and development in the growing habitat, such as high humidity, while Gmelina arbore growth can grow and develop well in real dry season habitat conditions (Sukriati, 2018). The difference in the Important Value Index of Dysoxylium gaudichadianu and Gmelina arbore which is quite significant, it can be assumed that the nature and ability to adapt affects the level of presence (frequency) of a plant species, because one of the major factors of Important Value Index is presence, where the presence of a species indicates the ability to adapt to the habitat and a wide tolerance for the environment (Hidayat, 2018).

Table 3.4. Importance Value Index For Poles Strata

\begin{tabular}{llllll}
\hline No & Species & $\begin{array}{l}\text { Relative } \\
\text { density }(\%)\end{array}$ & $\begin{array}{l}\text { Relative } \\
\text { frequency }(\%)\end{array}$ & $\begin{array}{l}\text { Relative } \\
\text { dominance } \\
(\%)\end{array}$ & $\begin{array}{l}\text { Important Value } \\
\text { Index }(\%)\end{array}$ \\
\hline 1 & Alstonia scholaris & 9,37 & 10,00 & 12,42 & 31,79 \\
2 & Azadirachta indica & 3,12 & 3,33 & 1,405 & 7,86 \\
3 & Baringtonia racemosa & 6,25 & 6,66 & 8,976 & 21,89 \\
4 & Calophyllum inophyllum & 3,12 & 3,33 & 1,835 & 8,294 \\
5 & Dendrocnide stimulans & 6,25 & 6,66 & 2,438 & 15,35 \\
6 & Dysoxylium gaudichadianun & 12,50 & 13,33 & 24,61 & 50,44 \\
7 & Dysoxylium sp & 6,25 & 6,66 & 3,728 & 16,64 \\
8 & Ficus racemosa & 3,12 & 3,33 & 2,868 & 9,32 \\
9 & Ficus salicifolia & 3,12 & 3,33 & 1,835 & 8,29 \\
10 & Ficus seftica & 6,25 & 6,66 & 2,81 & 15,73 \\
11 & Ficus sur & 9,37 & 10,00 & 8,661 & 28,04 \\
12 & Ficus variegate & 12,50 & 6,66 & 11,16 & 30,32 \\
13 & Gmelina arborea & 3,12 & 3,33 & 1,405 & 7,86 \\
14 & Shorea macrophylla & 3,12 & 3,33 & 2,868 & 9,32 \\
15 & Shorea sp & 6,25 & 3,33 & 8,288 & 17,87 \\
16 & Tabernamontana sphaeracorpa & 6,25 & 10,00 & 4,703 & 20,95 \\
\hline & Totals & 100 & 100 & 100 & 300 \\
\hline
\end{tabular}

Plants with tree strata are rarely found in the Lowang Gali forest tourism. This is due to the expansion of the tourism area so that the trees are old, so that from all the observation plots found tree strata as many as 34 stands. The highest Important Value Index of tree strata is Alstonia scholaris (45.15\%) and Dysoxylium gaudichadianun (45.15\%) (Table 3.5), this proves that the two types are able to compete, grow and adapt well to the Lowang Gali forest tourism area. Diversity Index of Plant Species The index value of the diversity of the vegetation strata of Lowang Gali forest tourism shows a value of more than $1(>1)$, namely the diversity value of the seedlings strata of 2,707 , sapling strata of 2,869, pole strata of 2,653 and tree strata of 2,548 (Table 3.6). The results of the 
research and calculations show that the vegetation of the Lowang Gali forest tourism is in moderate diversity.

Table 3.5. Importance Value Index For Trees Strata

\begin{tabular}{llllll}
\hline No & \multicolumn{1}{c}{ Species } & $\begin{array}{c}\text { Relative } \\
\text { density } \\
(\%)\end{array}$ & $\begin{array}{c}\text { Relative } \\
\text { frequency } \\
(\%)\end{array}$ & $\begin{array}{c}\text { Relative } \\
\text { dominance } \\
(\%)\end{array}$ & $\begin{array}{c}\text { Important } \\
\text { Value } \\
\text { Index }(\%)\end{array}$ \\
\hline 1 & Alstonia scholaris & 14,72 & 15,15 & 15,28 & 45,15 \\
2 & Azadirachta indica & 2,943 & 3,03 & 2,392 & 8,365 \\
3 & Baringtonia racemosa & 11,77 & 12,12 & 10,09 & 33,99 \\
4 & Calophyllum inophyllum & 2,943 & 3,03 & 2,392 & 8,365 \\
5 & Ceiba speciosa & 2,943 & 3,03 & 2,392 & 8,365 \\
6 & Dendrocnide stimulans & 5,887 & 6,061 & 5,869 & 17,82 \\
7 & Dysoxylium gaudichadianun & 14,72 & 15,15 & 15,28 & 45,15 \\
8 & Dysoxylium sp & 8,83 & 6,061 & 9,396 & 24,29 \\
9 & Ficus racemosa & 5,887 & 6,061 & 6,248 & 18,19 \\
10 & Ficus salicifolia & 5,887 & 6,061 & 5,491 & 17,44 \\
11 & Ficus variegate & 5,887 & 6,061 & 7,15 & 19,1 \\
12 & Gmelina arborea & 2,943 & 3,03 & 2,745 & 8,719 \\
13 & Salix tetrasperma & 5,887 & 6,061 & 6,65 & 18,6 \\
15 & Shorea macrophylla & 5,887 & 6,061 & 5,869 & 17,82 \\
16 & Shorea sp & 2,943 & 3,03 & 2,745 & 8,719 \\
\hline & Total & 100,1 & 100 & 100 & 300,1 \\
\hline
\end{tabular}

Table 3.6. Diversity Index Of Plant Species

\begin{tabular}{|c|c|c|c|c|c|}
\hline No & Species & Seedling & Sapling & Pole & Tree \\
\hline 1 & Alstonia scholaris & 0,218 & 0,216 & 0,222 & 0,282 \\
\hline 2 & Azadirachta indica & 0,063 & 0 & 0,108 & 0,104 \\
\hline 3 & Baringtonia racemosa & 0,106 & 0,119 & 0,173 & 0,252 \\
\hline 4 & Brugmansia sp & 0,106 & 0,157 & 0 & 0 \\
\hline 5 & Calophyllum inophyllum & 0,106 & 0,119 & 0,108 & 0,104 \\
\hline 6 & Ceiba speciosa & 0 & 0,119 & 0 & 0,104 \\
\hline 7 & Dendrocnide stimulans & 0,106 & 0,189 & 0,173 & 0,167 \\
\hline 8 & Dysoxylium gaudichadianun & 0,256 & 0,157 & 0,26 & 0,282 \\
\hline 9 & Dysoxylium sp & 0,106 & 0,189 & 0,173 & 0,214 \\
\hline 10 & Ficus racemosa & 0,106 & 0,072 & 0,108 & 0,167 \\
\hline 11 & Ficus salicifolia & 0 & 0 & 0,108 & 0,167 \\
\hline 12 & Ficus seftica & 0,272 & 0,189 & 0,173 & 0 \\
\hline 13 & Ficus sur & 0,238 & 0,157 & 0,222 & 0 \\
\hline 14 & Ficus variegate & 0,195 & 0,189 & 0,26 & 0,167 \\
\hline 15 & Gmelina arborea & 0 & 0,119 & 0,108 & 0,104 \\
\hline 16 & Leuccaena sp & 0,141 & 0,189 & 0 & 0 \\
\hline 17 & Salix tetrasperma & 0,106 & 0,157 & 0 & 0,167 \\
\hline 18 & Shorea macrophylla & 0 & 0,072 & 0,108 & 0,167 \\
\hline 19 & Shorea sp & 0,141 & 0 & 0,173 & 0,104 \\
\hline 20 & Sumbucus javanica & 0,195 & 0,189 & 0 & 0 \\
\hline 21 & Syzygium аqиеит & 0,106 & 0,119 & 0 & 0 \\
\hline 22 & Tabernamontana sphaeracorpa & 0,141 & 0,157 & 0,173 & 0 \\
\hline \multicolumn{2}{|r|}{ Total } & 2,707 & 2,869 & 2,653 & 2,548 \\
\hline
\end{tabular}

\section{CONCLUSION}

The composition of Lowang Gali forest tourism is composed of 22 types consisting of 14 families. The highest Important Value Index for seedlings was Ficus seftica (23.39\%), the highest Important Value Index for saplings was Alstonia scholaris (19.80\%), 
the highest Important Value Index for pole strata was Dysoxylium gaudichadianun (50.44\%) and the highest Important Value Index for tree strata was Alstonia scholaris (45.15\%) and Dysoxylium gaudichadianun (45.15\%). The index value of plant species diversity in the Lowang Gali forest tourism area is more than $1\left(1 \leq \mathrm{H}^{\prime} \leq 3\right)$ which indicates moderate diversity.

\section{E. REFERENCES}

Hidayat, M. (2018). Analisis Vegetasi Dan Keanekaragaman Tumbuhan Di Kawasan Manifestasi Geotermal Ie Suum Kecamatan Mesjid Raya Kabupaten Aceh Besar. BIOTIK: Jurnal Ilmiah Biologi Teknologi Dan Kependidikan, 5(2), 114. https://doi.org/10.22373/biotik.v5i2.3019.

Martono, D.S. 2012. Analisis Vegetasi Dan Asosiasi Antara Jenis-Jenis Pohon Utama Penyusun Hutan Tropis Dataran Rendah di Taman Nasional Gunug Rinjani Nusa Tenggara Barat. Madiun: Universitar Merdeka Madiun.

Monk K.A, De Freetes Y, Liley GR. 1997. The Ecology of Nusa Tenggara \& Maluku. Periplus, Hongkong.

Nur'aini, Syamsuardi, \& Arbain, A. (2013). Tumbuhan Ficus L. (Moraceae) di hutan konservasi Prof. Soemitro Djojohadikusumo, PT. Tidar Kerinci Agung (TKA), Sumatera Barat. Jurnal Biologi Universitas Andalas, 2(4), 235-241.

Rahman, F. A., Qayim, I., \& Wardiatno, Y. (2018). Carbon storage variability in seagrass meadows of Marine Poton Bako, East Lombok, West Nusa Tenggara, Indonesia. Biodiversitas, 19(5), 1626-1631. https://doi.org/10.13057/biodiv/d190505.

Rahman F.A, Rohyani I.S, Suripto, Hadi, A.P, Lestari D.P. 2019. Analisis Kualitas Perairan Terhadap Kemelimpahan Strata Pertumbuhan Vegetasi Mangrove Di Teluk Sereweh, Kabupaten Lombok Timur Nusa Tenggara Barat. Juranl Pendidikan Biologi Dan Sains (Penbios) 4 (2).

Restu I.W. 2002. Kajian Pengembangan Wisata Mangrove di Taman Hutan Raya Ngurah Rai Wilayah Pesisir Selatan Bali. [Tesis]. Bogor: Program Pasca Sarjana, Institut Pertanian Bogor.

Sofiah, S., Setiadi, D., \& Widyatmoko, D. (2013). Pola penyebaran, kelimpahan dan asosiasi bambu pada tumbuhan di Taman Wisata Alam Gunung Baung Jawa Timur. Berita Biologi, 12(2), 239-247.

Susila, I. W. W. (2014). Potensi dan Tataniaga Mimba (Azadirachta indica A. Juss) di Lombok. Jurnal Penelitian Hutan Tanaman, 12(2), 127-139. https://doi.org/10.20886/jpht.2014.11.2.127-139

Kusmana C, Istomo. 1995. Ekologi hutan. Fakultas Kehutanan IPB. Bogor. 